C. Mazroatul, et al., ALCHEMY jurnal penelitian kimia, vol. 12 (2016), no. 1, hal. 88-94

\title{
ANTI-HYPERCHOLESTEROLEMIA ACTIVITY OF ETHANOL EXTRACT Peperomia pellucid
}

\author{
Chasanah Mazroatul $^{\text {a*}}$, Glar Donia Deni ${ }^{\text {, }}$, Nur Ahmad Habibic, Gita Febri Saputri ${ }^{\text {d }}$ \\ ${ }^{a}$ Department of Public Health, Diponegoro University, Semarang, Indonesia \\ ${ }^{b}$ Department of Chemistry, Diponegoro University, Semarang, Indonesia. \\ ${ }^{c}$ Department of Nutritional Sciences, Diponegoro University, Semarang, Indonesia. \\ ${ }^{d}$ Department of Nursing, Diponegoro University, Semarang, Indonesia \\ *email : mazroatulc@gmail.com \\ DOI : 10.20961/alchemy.v12i1.948
}

Received 02 February 2016, Accepted 24 February 2016, Published 01 March 2016

\begin{abstract}
Hypercholesterolemia is a major cause of cardiovascular disease such as coronary heart disease. Betel water (Peperomia pellucida) is a type of plants that have antioxidant compounds that could delay, retard and prevent the oxidation of lipids, both enzymatic and non-enzymatic. This study aimed to determine the effect of ethanol extract Peperomia pellucida against total cholesterol, HDL, LDL, and triglycerides in the serum of white rats (Wistar) were given a diet aterogenetik, so it can be used as prevention of atherosclerosis. The active compounds contained in the water after screnning betel phytochemicals includes flavonoids, tannins, alkaloids, steroids and quinones. In vivo studies conducted by true experimental method with pre and post test with control group design. Rats were divided into 3 groups: group A positive control is given aterogenetik diet, group B and C were given diet Peperomia Pellucida aterogenetik and extract orally at a dose of $150 \mathrm{mg} / \mathrm{kg}$ and $300 \mathrm{mg} / \mathrm{kg}$. Diet aterogenetik given as much as 20 grams per day for 14 days. Data obtained include total cholesterol, HDL, LDL, and triglycerides were analyzed by statistical methods Paired $\mathrm{T}$ Test oneway ANOVA $(\mathrm{P}<0.05)$. The study of total cholesterol, HDL, LDL and triglycerides showed ethanol extract of Peperomia pellucida at a dose of $300 \mathrm{mg} / \mathrm{kg}$ body weight can lower total cholesterol and LDL significantly, but there was no significant decline in triglycerides and can increase HDL levels.
\end{abstract}

Keywords: anti-hypercholesterolemia, ethanol, Peperonia pellucia.

\section{INTRODUCTION}

Hyperlipidemia is a major cause of atherosclerosis. The incident related to the occurrence of coronary heart disease (CHD), cerebrovascular ischemia and peripheral vascular disease (Goodman \& Gilman, 2007). Coronary Heart Disease (CHD) is one of the many diseases that currently threaten public health and the cause of death in the world (Baraas, 1993). American Heart Association (2009) estimate the prevalence of CHD in the United States in 2004, approximately 13.2 million. The whole world got 50 million deaths each year due to CHD and 39 million of them are in developing countries (Boedhi, 2003). 
In 2002 the WHO estimates that 3.8 million men and 3.4 million women worldwide each year die of coronary heart disease (WHO, 2008).

Atherosclerosis is a progressive disease characterized by the accumulation cholesterol, low density lipoprotein (LDL), and fibrous elements in the large arteries that contribute to the severity of cardiovascular disease (Farias, 1996; Jeong, 2005). Increased total cholesterol and triglycerides are the factors causing the development of atherosclerosis and coronary heart disease (Farias, 1996; Jeong, 2005; Chobanian, 1991).

Betel water (Peperomia pellucida) is a type of plant that grows in Java and can live in all conditions (Wijaya and Monica, 2004). These plants are used by the people of Indonesia as an external medicine for treating headaches during the fever, and the essence of betel water is used as a stomach medicine (Wijaya and Monica, 2004).

In the previous study, Tarin (2012) explains the benefits of betel leaves water to treat gout and ulcers (abscesses). Many studies have shown that betel plant water at a dose of $150 \mathrm{mg} / \mathrm{kg}$ can give antipyretic effect (Khan et al., 2007), anti-inflammatory, antibacterial, hypoglycemic, and analgesic (Hasib et al., 2013). Majumder (2013) states that betel water containing the chemical compound class of glycosides, flavonoids, tannins and steroids/triterpenoids. However, there has been no research on betel water activity in lowering cholesterol levels. In this study, we aimed to test the anti-hypercholesterolemic activity of ethanol extract of betel water to rats by measuring the biochemical parameters in the blood serum of mice such as total cholesterol, low density lipoprotein (LDL), high density lipoprotein (HDL) and triglycerides. The hope betel water may be an alternative treatment of cardiovascular disease, especially coronary heart disease.

\section{METHODS}

\section{Material plants and Active Compounds Extraction}

Herba betel water (Peperomia pellucida) is obtained from Semarang area and identified by the taxonomy of plants in the laboratory of Biology, State University of Semarang. Betel dry water as much as 400 grams of pulverized until homogenous and macerated using ethanol. The ethanol extract was concentrated using a rotary evaporator to eliminate the solvent to form a viscous extract betel dark green water.

\section{Procedures}

\section{Animal Testing}

This study used 21 Wistar strain male rats 2 - 3 months old, weighing $200-250 \mathrm{~g}$ were obtained from the Laboratory of Biology, Faculty of Mathematics and Natural 
Sciences, State University of Semarang. Rats adapted to the state laboratory for 7 days by feeding standards. Feed given as much as 20 grams per head per day and water ad libitium during the study.

\section{Phytochemical screening Betel Water}

Phytochemical screening performed on dry bulbs and ethanol extract of betel water. Screening active compounds include alkaloids, flavonoids, tannins, saponins, quinones and steroid/triterpenoid. Screening is done in accordance with the method described by Harborne phytochemical 2005.

\section{Research Design}

This research is true experimental approach the randomized pretest posttest control group design. Mice that had been adapted for 7 days by feeding standards, on the 8 th day analysis of blood lipid levels to 3 rats taken randomly (Phase I). On the 9th day, all mice fed the atherogenic which consists of egg yolks and fat cattle for 2 weeks (14 days). Atherogenic feed given to improve cholesterol levels of mice. On day 22, an analysis of the blood lipid levels of the rats were taken randomly (Phase II). On day 24, mice were randomly divided into 3 treatment groups. Each group consists of 5 rats. The first group (control) were fed high-cholesterol, the second group (treatment 1) were fed standard series plus extract water at a dose of $150 \mathrm{mg} / \mathrm{kg} /$ day for 7 days and the third group (treatment 2) were fed a standard coupled with a dose of water extract of betel $300 \mathrm{mg} / \mathrm{kg}$ for 7 days. On day 33, an analysis of the blood lipid levels of all the mice in all three treatment groups (Phase III). Blood sampling for analysis of lipid levels is done in a way, blood is drawn through the eye by using the disposable syringe $3 \mathrm{~mL}$ size as much as 2 $\mathrm{mL}$. Blood in the syringe is stored in the ice container until ready analyzed blood lipid levels which include levels of TPC, LDL cholesterol, HDL cholesterol, and triglycerides (TG). Procedure analysis of blood lipid levels using enzymatic colorimetric method.

\section{Data Analysis}

The data collected is of primary data of inspection levels lipid profile of Wistar rats. The data is differentiated for each treatment group and control group were then analyzed by the statistical test. First time test data normality by the Shapiro-Wilk test. If the data were normally distributed parametric test followed by One Way Anova, if acquired significant difference $(\mathrm{P}<0.05)$ then proceed with the independent $\mathrm{T}$ test. However, if the distribution is not normal if the test then analyzed by the non parametric test of KruskalWallis, if $\mathrm{P}<0.05$ then there are significant differences; If $\mathrm{P}>0.05$, there is no significant 
difference, and if obtained significant difference followed by Mann-Whitney statistical test.

\section{DISCUSSION}

Phytochemical screening on betel water to determine the chemical constituents of the plant to be used. Phytochemical screening performed on crude drugs and extracts of betel water for comparing the chemical content after the extraction process. Phytochemical screening results can be seen in Table 1.

Table 1. Test Results Phytochemicals Betel Water

\begin{tabular}{ccc}
\hline Phytochemical test & Powder & Extract \\
\hline Alkaloids & + & + \\
Saponin & + & - \\
Flavonoids & + & + \\
Tanin & + & + \\
Quinone & + & + \\
Steroids & + & + \\
Triterpenoids & - & - \\
\hline
\end{tabular}

Table 1 shows that the phytochemical screening on betel water powders containing the compound were almost the same, but there are differences that the saponin. The results are consistent with studies that have been reported by Majumder, 2011.

Table 2. Effect of Ethanol Extracts Against Biochemical Parameters

\begin{tabular}{|c|c|c|c|c|c|}
\hline Material & $\begin{array}{l}\text { Dose } \\
(\mathrm{mg} / \mathrm{kg})\end{array}$ & $\begin{array}{c}\text { Total } \\
\text { Cholesterol } \\
(\mathrm{mg} / \mathrm{dl})\end{array}$ & HDL (mg/dl) & LDL (mg/dl) & $\begin{array}{l}\text { Trigliserida } \\
\text { (mg/dl) }\end{array}$ \\
\hline Control & 0 & $\begin{array}{l}64.41 \pm 8,21 \\
(+19.24 \pm 9.18)\end{array}$ & $\begin{array}{l}17.6 \pm 3.9 \\
(+0.4 \pm 0.70)\end{array}$ & $\begin{array}{l}34.5 \pm 10.12 \\
(+10.88 \pm 9.34)\end{array}$ & $\begin{array}{l}61.55 \pm 15.48 \\
(+21.76 \pm 1.29)\end{array}$ \\
\hline Treatment 1 & 150 & $\begin{array}{l}50.40 \pm 8.33 \\
(+4.37 \pm 2.3)\end{array}$ & $\begin{array}{l}33 \pm 3.74 \\
(-2.6 \pm 2.199)\end{array}$ & $\begin{array}{l}11.288 \pm 9.51 \\
(-8.64 \pm 10.79)\end{array}$ & $\begin{array}{l}30.58 \pm 9.18 \\
(+8.16 \pm 4.05)\end{array}$ \\
\hline Treatment 2 & 300 & $\begin{array}{l}37.27 \pm 8.47 \\
(-13.80 \pm 8.4)\end{array}$ & $\begin{array}{l}24.2 \pm 3.898 \\
(-5.8 \pm 8.28)\end{array}$ & $\begin{array}{l}10.55 \pm 5.46 \\
(-7.56 \pm 5.47)\end{array}$ & $\begin{array}{l}12.57 \pm 4.73 \\
(-2.49 \pm 0.64)\end{array}$ \\
\hline
\end{tabular}

In this study, betel water is extracted using ethanol and tested hypercholesterolemia inhibitory activity against biochemical parameters in rat serum. Results of in vivo experiments in rats is shown in Table 2.

Cholesterol is one of the biomolecules contained in the body and are classified into lipids. Cholesterol and triglycerides are very important for the biosynthesis of hormones, bile acids and vitamin $\mathrm{D}$, and also as an energy reserves. However, when the levels of cholesterol in the blood is too high will lead to atherosclerotic disease and other cardiovascular diseases. High cholesterol in the blood is influenced by the cholesterol synthesized by the liver and cholesterol obtained from food. This study, male rats (Wistar) 
were fed a diet high cholesterol derived from egg yolks and beef fat. According to Wells et al., 1987 stating that feeding fat and egg yolk can increase weight loss is accompanied by an increase in serum cholesterol animals. In this study, the ethanol extract at a dose of 300 $\mathrm{mg} / \mathrm{kg}$ gives a decrease $(\mathrm{P}<0.05)$ significant serum cholesterol levels in rats.

On the other side, low density lipoprotein (LDL) carry cholesterol from the liver to the network. While high-density lipoprotein (HDL) facilitate in bringing koleterol of tissues to the liver for catabolism peroses. Therefore HDL cholesterol lowering effect on tissues and increase the ratio between HDL and LDL suggested. Increase in HDL can reduce levels of LDL- cholesterol to reduce the risk of cardiovascular disease.

Betel water in phytochemical test contains a steroids which has been shown to lower cholesterol levels by pressing the synthesis of cholesterol. This capability is caused by steroids structure that resembles cholesterol. The possibility steroids can replaces cholesterol from mixed micelles because it is more hydrophobic than cholesterol (Child and Kuksis, 1986). This replacement causes a decrease in cholesterol micelles concentration and consequently decrease the absorption of cholesterol (Child and Kuksis, 1983).

Hypercholesterolemia will increase the level of serum lipid peroxidation in hypercholesterolemic rabbits and guinea pigs (Das et al., 2000). This is proven by studies Gulcan et al., 2006 stating that the level of lipid peroxidation in cholesterol-rich group is relatively higher than the control group of animals. Flavonoids in ekstak can reduce lipid peroxidation and liver enzymes, as well as increase the activity of the antioxidant defense system in rats (Kanter et al., 2003). Diet hypercholesterolemia caused a small reduction in plasma concentrations of NO metabolites in the presence of tannins in the extract will increase NO metabolites (Gulcan et al., 2006). This influence may be due to the tannins contained in the water can reduce hypercholesterolemia betel as effective in inhibiting 3hydroxy-3-methylglutaryl coenzyme A (HMG-CoA) reductase inhibitors which may be effective in hiperkolestrolemia (Chang et al., 2001).

\section{CONCLUSION}

Betel water (Peperomia pellucida) obtained in the area of Semarang and extracted using ethanol contain chemicals such as tannins, flavonoids, steroids, alkaloids, and quinones. Diet aterogenetik given to Wistar strain rats for 14 days. Data obtained include total cholesterol, HDL, LDL, and triglycerides were analyzed by statistical methods Paired $\mathrm{T}$ Test oneway ANOVA $(\mathrm{P}<0.05)$. The study of total cholesterol, HDL, LDL, and 
triglycerides showed ethanol extract of Peperomia pellucida. Dose of $300 \mathrm{mg} / \mathrm{kg}$ body weight can lower total cholesterol and LDL significantly, but there was no significant decrease in triglycerides and can increase HDL levels Wistar rats.

\section{ACKNOWLEDGEMENT}

Thanks to the Directorate-General for Research and Higher Education Community Service that has helped financially in this research keberjalanan. Thanks to Bagoes Widjanarko who have provided input for this study runs.

\section{REFERENCE}

Alam, K., Moizur, R., and Shariful, I., 2007, Antipyretic Activity of Peperomia pellucida Leaves in Rabbit, Turkiesh Journal of Biology, vol. 32, pp. 37-41.

Alam, K., Moizur, R., and Shariful, I., 2010, Isolation and Bioactivity of a Xanthone Glycoside From Peperomia pellucida, Journal Life Sciences and Medicine Research, vol. 1, pp. 1-10.

Chang, J.J., Chen, T.H., Chan P., Chen, Y.J., Hsu, F.L., Lo, M.Y., and Lin, J.Y., 2001, The In Vitro Inhibitory Effect of Tannin Derivatives on 3-hydroxy-3-methylglutarylcoenzyme A Reductase On Vero Cells, Journal of Pharmacology, vol. 62, pp. 2248.

Child, P., and Kuksis, A., 1983, Critical Role of Ring Structure in The Differential Uptake of Cholesterol and Plant Sterols by Membrane Preparations In Vitro, Journal of Lipid Research, vol. 24, pp. 1196-1209.

Child, P., and Kuksis, A., 1986, Investigation of The Role of Micellar Phospholipid in The Preferential Uptake of Cholesterol Over Sitosterol by Dispersed Rat Jejunal Villus Cells, Journal Biochemistry and Cell Biololgy, vol. 64, pp. 847-853.

Das, S., Vasisht, S., Das S.N., and Srivastava, L.M., 2000, Correlation Between Total Antioxidant Status and Lipid Peroxidation in Hypercholesterolaemia, Current Science, vol. 78, pp. 486-487.

Ganiyat, K., Patricia, A., and Bamidele, B., 2011, Phytochemical, Toxicity, Antimicrobial and Antioxidant Screening of Leaf Extracts of Peperomia pellucida From Nigeria, Journal Advances in Environmental Biology, vol. 5, no. 12, pp. 3700-3709.

Gulcan, A., Esra, K., Abdullah, E., Erdem, Y., and Ismail, K., 2006, Antihypercholesterolaemic and Antioxidant Activity Assessment of Some Plants Used as Remedy in Turkish Folk Medicine, Journal of Ethnopharmacology, vol. 107, pp. 418-423.

Harborne, J.B., 2005, Phytochemical Methods, New Delhi: Springer Pvt. Ltd., India.

Hasib, S., Shotabdi, S., Sagar, K., Rashedul, H., Mofizur, R., and Sangita, P., 2013, Hypoglycemic, Anti-inflammatory and Analgesic Activity of Peperomia pellucide (L.) HBK (Piperacae) Bangladesh, International Journal of Pharmaceutical Sciences and Research 4, vol. 1, pp. 458-463. 
Jeong, J.H., Kim, J.S., Lee, B.C., Min, Y.S., Kim, D.S., Ryu, J.S., Soh, K.S., Seo, K.M., and Sohn, U.D., 2005, Influence of Exposure to Electromagnetic Field on The Cardiovascular System, Auton Autacoid Pharmacol, vol. 25, pp. 17-23.

Kanter, M., Meral, I., Dede, S., Cemek, M., Ozbek, H., Uygan, I., and Gunduz, H., 2003, Effects of Nigella Sativa L. and Urtica Dioica L. on Lipid Peroxidation, Antioxidant Enzyme Systems and Some Liver Enzymes in CCl4-Treated Rats, Journal of Veterinary Medicine A, vol. 50, pp. 264-8.

Khan, A., Moizur, R., Shariful, I., 2007, Antipyretic Activity of Peperomia pellucida Leaves in Rabbit, Turkish Journal of Biology, vol. 32, pp. 37-41.

Majumder Pulak, 2013, Phytochemical, Pharmacognostical and Physicochemical Standardization of Peperomia pellucide (L.) HBK. Stem, International Journal of Comprehensive Pharmacy 8, vol. 6. 